\section{S2A:5 DEVELOPMENT AND VALIDATION OF A SCORE TO PREDICT THE RISK OF SEVERE INFECTION IN SLE}

'B Segura, ${ }^{2}$ Rúa-Figueroa, ${ }^{3} \mathrm{JM}$ Pego-Reigosa, ${ }^{4} \mathrm{~V}$ Del Campo, ${ }^{5} \mathrm{D}$ Isenberg, ${ }^{5} \mathrm{~A}$ Rahman. ${ }^{1}$ Insular University Hospital, Rheumatology Department, Las Palmas de Gran Canaria, Spain; ${ }^{2}$ Doctor Negrín University Hospital, Rheumatology Department, Las Palmas de Gran Canaria, Spain; ${ }^{3}$ Biomedical Research Institute of Vigo (IBIV), University Hospital Complex of Vigo, Rheumatology Department, Vigo, Spain; ${ }^{4}$ Biomedical Research Institute of Vigo (IBIV), University Hospital Complex of Vigo, Preventive Medicine Department, Vigo, Spain; ${ }^{5}$ University College London Hospital, Centre for Rheumatology, Department of Medicine, London, UK

10.1136/lupus-2018-abstract.8

Purpose To develop a predictive risk score that assesses the probability of severe infection in SLE patients and to test it in an independent cohort.

Methods The SLE severe infection score (SLESIS) was developed using data from the RELESSER (Spanish Society of Rheumatology Lupus Registry) cohort of 3658 SLE patients using a Cox regression model for repeated events (AndersenGill) The results were expressed as hazard ratio (HR) of developing one serious infection/1000 patient-years for patients with the risk factor compared to those without that factor. SLESIS for an individual patient is the sum of the HR values of all factors present at that time.

SLESIS was validated using retrospective data from the UCLH (University College London Hospital) cohort including 699 SLE patients.

Results The risk factors included in SCORE and their HR calculated from RELESSER data are shown in table 1. From 699 SLE UCLH patients, 98 (14\%) developed serious infection.

\section{Abstract S2A:5 Table 1}

\begin{tabular}{|l|l|l|l|}
\hline Risk factor & B & P-value & HR \\
\hline $\begin{array}{l}\text { Age at diagnosis } \\
\text { (>46 years old) }\end{array}$ & 0.1163 & 0.001 & 1.12 \\
\hline $\begin{array}{l}\text { Latin American } \\
\text { ethnicity }\end{array}$ & 0.427 & 0.001 & 2.40 \\
\hline $\begin{array}{l}\text { Corticosteroids } \\
\text { (>10 me/day) at } \\
\text { time } \\
\text { calculating scorE } \\
\text { of }\end{array}$ & 0.2878 & 0.001 & 1.33 \\
\hline $\begin{array}{l}\text { Sex=male } \\
\text { hospitalization } \\
\text { (for SLE) }\end{array}$ & 1.0049 & $<0.00001$ & 2.73 \\
\hline $\begin{array}{l}\text { Katz index } \\
\text { any time }\end{array}$ & 0,062 & 0.002 & 1.06 \\
\hline $\begin{array}{l}\text { Prior infection at } \\
\text { Previous }\end{array}$ & 0.8739 & $<0.0001$ & 2.40 \\
\hline
\end{tabular}

We compared these patients with 111 SLE controls who never suffered serious infection. The characteristics of the SLE infection and SLE non-infection groups are summarised in table 2.

Median SLESIS at diagnosis in patients with infection was 4.27 (IQR 3.18) which was significantly higher than in the control group (Median 2.55, IQR 3.79) ( $\mathrm{z}=3.341 ; \mathrm{p}=0.0008$ ). Median SLESIS just before infection was 5.3 (IQR 3.68) which was significantly higher compared to SLESIS at diagnosis $(\mathrm{z}=-5.733 ; \mathrm{p} \leq 0.001)$ in those patients or SLESIS measured at the same time post-diagnosis in the non-infected group (Median 3.73 RI 3.7) ( $\mathrm{z}=-4.765, \mathrm{p} \leq 0.001)$.

By Receiver Operator Characteristic analysis, we defined three possible cut-offs to distinguish patients with and without infection. For SLESIS just before infection, the area under the ROC curve was 0.75 (CI: 0.66 to 0.84 ) and the three selected cut offs $(3.67,3.79,4.24)$ reached a sensitivity of $90 \%$ and specificity of $50 \%$.

Conclusion We have developed a score for predicting risk of serious infection in SLE and validated it in an independent cohort. Given the potential mortality from such infections, SLESIS could be clinically useful though the moderate sensitivity and specificity necessitate caution and further prospective studies.

\section{S2A:6 SOLUBLE UROKINASE PLASMINOGEN ACTIVATOR RECEPTOR (SUPAR) PREDICTS THE DEVELOPMENT OF ORGAN DAMAGE OVER 5 YEARS IN SYSTEMIC LUPUS ERYTHEMATOSUS: RESULTS FROM THE SLICC INCEPTION COHORT}

${ }^{1} \mathrm{H}$ Enocsson, 'L Wirestam, ${ }^{1} \mathrm{~J}$ Wetterö, ${ }^{1} \mathrm{~T}$ Skogh, The Slicc Group2 ${ }^{2},{ }^{3,4} \mathrm{IN}$ Bruce, ${ }^{1} \mathrm{C}$ Sjöwall. ${ }^{1}$ Rheumatology, Division of Neuro and Inflammation Sciences,Department of Clinical and Experimental Medicine Linköping Uni, Linköping, Sweden; ${ }^{2}$ The Systemic Lupus International Collaborating Clinics (SLICC) Group; ${ }^{3}$ Arthritis Research UK Centre for Epidemiology, Centre for Musculoskeletal Research, The University of Manchester, Manchester, UK; ${ }^{4}$ NIHR Manchester Musculoskeletal Biomedical Research Unit, Central Manchester University Hospitals NHS Foundation Trust, Manchester, UK

\subsection{6/lupus-2018-abstract.9}

Background The urokinase plasminogen activator receptor (suPAR) participates in proteolysis, migration and adhesion. Receptor shedding yields a soluble form (suPAR) that has emerged as a promising severity biomarker in malignancies, inflammatory and infectious diseases. Previously, suPAR was shown to reflect accumulated organ damage in systemic lupus erythematosus (SLE). Here, we investigate suPAR as a potential predictor of future organ damage in patients with recent-onset SLE.

Methods 345 SLE cases (at least 4 ACR criteria) from North America, Europe and Asia were included. All patients were from the SLICC inception cohort and were selected based on a minimum of 5 years follow-up and absence of organ damage (SLICC/ ACR damage index; SDI $>0$ ) at inclusion. Patients were enrolled within 15 months of diagnosis. Estimated glomerular filtration rate (eGFR) was available for 180 patients. Serum suPAR levels were measured by ELISA at inclusion only, and levels were related to SDI after 5 years of follow-up. Age- and sex-matched controls $(1: 1)$ were from the Swedish population. 
Abstract S2A:5 Table 2

\begin{tabular}{|c|c|c|c|}
\hline & SLE-infection ( $n=98)$ & SLE-non infection ( $n=111)$ & $P$ value \\
\hline Gender, n (\%) & $\begin{array}{l}\text { - } \quad \text { Females: } 90(91.8) \\
\text { - } \quad \text { Males:8 }(8.2)\end{array}$ & $\begin{array}{ll}\text { - } & \text { Females: } 103(92.8) \\
\text { - } & \text { Males: } 8(7.2)\end{array}$ & ns \\
\hline $\begin{array}{l}\text { Median age at } \\
\text { diagnosis of SLE (IQR) }\end{array}$ & $30.5(27)$ & $31(18)$ & ns \\
\hline $\begin{array}{l}\text { Mean age at time of } \\
\text { infection (IQR) }\end{array}$ & $43(25)$ & & \\
\hline $\begin{array}{l}\text { Ethnicity, } \mathbf{n}(\%) \\
\text { Caucasian } \\
\text { Latin American } \\
\text { Afro-Caribbean } \\
\text { Asian } \\
\text { Other }\end{array}$ & $\begin{array}{c}48(49) \\
3(3.06) \\
28(28.6) \\
7(7.1) \\
12(12.2)\end{array}$ & $\begin{array}{l}72(64.9) \\
2(1.8) \\
20(18.02) \\
6(5.4) \\
12(10.8)\end{array}$ & ns \\
\hline $\begin{array}{l}\text { Median length of } \\
\text { follow-up (IQR) }\end{array}$ & $9.5(14)$ yrs & $14(9)$ yrs & ns \\
\hline $\begin{array}{l}\text { Previous infection } \\
\text { before SLE diagnosis, } \\
\mathrm{n}(\%)\end{array}$ & $16(16.3)$ & $3(2.7)$ & 0.001 \\
\hline $\begin{array}{l}\text { Previous } \\
\text { hospitalizations (SLE), } \\
\text { n(\%) }\end{array}$ & $55(56.1)$ & $36(32.4)$ & 0.001 \\
\hline $\begin{array}{l}\text { SLE main features } \\
\text { (cumulative), } \mathrm{n}(\%)\end{array}$ & $\begin{array}{cc}\text { - } & \text { Skin disease } 76(77.6) \\
\text { - } & \text { Joint disease } 72(73.5) \\
\text { - } & \text { Renal disease } 42(42.9) \\
\text { - } & \text { CNS disease } 13(13.1) \\
\text { - } & \text { Serositis } 19(19.4)\end{array}$ & $\begin{array}{cc}\text { - } & \text { Skin disease } 67(60.3) \\
- & \text { Joint disease } 101(90.5) \\
- & \text { Renal disease } 29(26.1) \\
- & \text { CNS disease } 12(10.8) \\
\text { - } & \text { Serositis } 33(29.7)\end{array}$ & $\begin{array}{c}-0.012 \\
-0.001 \\
-0.011 \\
\text { ns } \\
\text { ns }\end{array}$ \\
\hline $\begin{array}{l}\text { Laboratory findings } \\
\text { (cumulative), } \mathrm{n}(\%)\end{array}$ & $\begin{array}{ll}- & \text { Neutropenia } 33(33.7) \\
- & \text { Lymphopenia } 76(77.6) \\
- & \text { Decreased C } 3 / C 4 \text { levels } \\
& 57(58.2) \\
-\quad & \text { Elevated dsDNA-Ab } 67 \\
& (68.4) \\
\end{array}$ & $\begin{array}{ll}- & \text { Neutropenia } 19[17.1) \\
- & \text { Lymphopenia } 73(65.8) \\
- & \text { Decreased } C 3 / C 4 \text { levels } \\
& 50(45.1) \\
\text { - } & \text { Elevated dsDNA } 66(60)\end{array}$ & $\begin{array}{c}0.006 \\
\text { ns } \\
\text { ns }\end{array}$ \\
\hline $\begin{array}{l}\text { Previous drug } \\
\text { treatment, } \mathrm{n}(\%)\end{array}$ & $\begin{array}{ll}\text { - } & \text { Steroids (at any time) } 89 \\
& (90.8) \\
- & \text { No Hydroxychloroquine } \\
& 32(32.7) \\
- & \text { MMF } 36(34.7) \\
- & \text { AZA } 47(48) \\
- & \text { Cyclophosphamide } 28 \\
& (28.6) \\
\text { - } & \text { Biological treatment } 26 \\
\text { (26.5) }\end{array}$ & $\begin{array}{ll}\text { - } & \text { Steroids (at any time) } 43 \\
& \text { (38.7) } \\
\text { - } & \text { No Hydroxychloroquine } \\
& 25(25.2) \\
\text { - } & \text { MMF } 28(25.2) \\
\text { - } & \text { AZA } 35 \text { (26.1) } \\
\text { - Cyclophosphamide } 13 \\
\text { (11.7) } \\
\text { Biological treatment } 25 \\
\text { (22.5) }\end{array}$ & $\begin{array}{c}<0.001 \\
n s \\
n s \\
0.02 \\
<0.001 \\
\text { ns }\end{array}$ \\
\hline $\begin{array}{l}\text { Patients with >1 } \\
\text { Infection } \\
\text { Death following } \\
\text { infection }\end{array}$ & $\begin{array}{l}18(18.4 \%) \\
26(26.5 \%)\end{array}$ & & \\
\hline
\end{tabular}

Results Baseline suPAR levels were higher in patients who acquired damage (SDI $>1)$ over a 5 year period $(n=33)$ compared to patients without damage development $(\mathrm{n}=246 ; \mathrm{p}<0.001)$ and controls $(n=345 ; p=0.007)$ (figure 1). There were no significant differences in suPAR with regard to ethnicity (Caucasians vs non-Caucasians) or sex in patients/controls, but a weak correlation between age and suPAR among controls $(\mathrm{p}<0.001, \mathrm{r}=0.23)$. No correlations $(\mathrm{r}>0.2)$ were found between suPAR and disease activity (SLEDAI-2K), corticosteroid dose or eGFR. Logistic regression revealed significant impact of baseline suPAR on future damage (SDI $>1) \quad(p=0.014$; area under curve, $\mathrm{AUC}=0.64$ ) and the predictive value became stronger after adjustment for age, sex, ethnicity and corticosteroid dose $(p=0.008 ; A U C=0.74)$. Examining individual components of SDI revealed significant impact of suPAR on musculoskeletal damage $(\mathrm{SDI}>0)(\mathrm{p}=0.018 ; \mathrm{AUC}=0.66)$ lso when adjusting for covariates $(\mathrm{p}=0.020 ; \mathrm{AUC}=0.68)$.

Conclusion Prognostic biomarkers of disease severity in SLE could identify patients in need of tight control and improved treatment strategies. Here, suPAR is for the first time shown to have predictive potential of damage accrual in SLE. Continued follow-up of patients could elucidate the association between suPAR and damage in specific organ domains. 


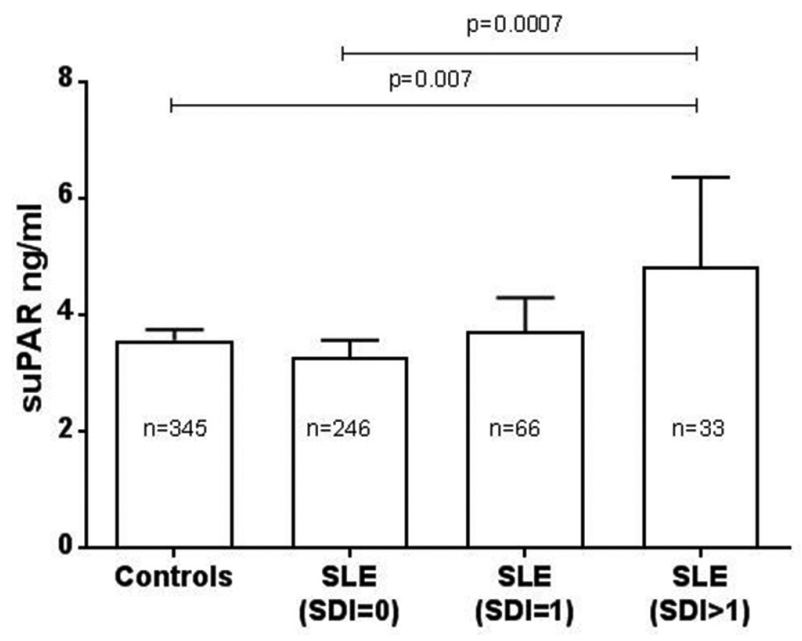

Abstract S2A:6 Figure 1

S2d - Lupus nephritis

\section{S2D:5 EXOSOMES TARGET RENAL TUBULAR EPITHELIAL CELLS TRANSFERRING INFLAMMATORY EPSTEIN-BARR VIRUS-ENCODED SMALL RNA (EBER1) IN LUPUS NEPHRITIS PATIENTS}

${ }^{1}$ SR Baglio, ${ }^{1} \mathrm{~N}$ Masoumi, ${ }^{2} \mathrm{MW}$ Tsang-a-Sjoe, ${ }^{1} \mathrm{MA}$ van Eijndhoven, ${ }^{3} \mathrm{KM}$ Heutinck, ${ }^{1} \mathrm{ES} J$ Jordanova, ${ }^{4} \mathrm{RJ}$ ten Berge, ${ }^{5} \mathrm{~K}$ Grundberg, ${ }^{6} \mathrm{RM}$ Schiffelers, ${ }^{1 J} \mathrm{~J}$ van den Wetering, ${ }^{1} \mathrm{~K}$ de Wildt, 'SM Verkuijlen, ${ }^{7} \mathrm{~J}$ Roelofs, ${ }^{2} \mathrm{IE}$ Bultink, ${ }^{1} \mathrm{JM}$ Middeldorp, ${ }^{2} \mathrm{AE}$ Voskuyl, ${ }^{1} \mathrm{DM}$ Pegtel. ${ }^{1}$ Department of Pathology, Exosomes Research Group, VU University Medical Centre, Amsterdam, The Netherlands; ${ }^{2}$ Amsterdam Rheumatology and immunology Centre at VU University Medical Centre, Amsterdam, The Netherlands; ${ }^{3}$ Department of Nephrology, VU University Medical Centre, Amsterdam, The Netherlands; ${ }^{4}$ Department of Internal Medicine, Experimental Immunology and Renal Transplant Unit, Amsterdam, The Netherlands; ${ }^{5}$ Department of Pathology, Radboud University, Nijmegen, The Netherlands; ${ }^{6}$ Department of Clinical Chemistry, Utrecht University, Amsterdam, The Netherlands; 'Department of Pathology, Academic Medical Centre, Amsterdam, The Netherlands
In systemic lupus erythematosus (SLE) antiviral defenses are chronically activated, resulting in over-activity of the type I interferon (IFN) pathway. Studies in lupus-prone mice suggest that immune complexes associated with endogenous nucleic acids drive renal inflammation, a major cause of SLE-morbidity. However, the origin and nature of the extracellular nucleic acids driving inflammation in human lupus nephritis (LN) are incompletely understood.

Here we provide evidence that extracellular vesicles (EVs) can deliver a pro-inflammatory small RNA cargo into renal tubular epithelial cells (TECs). In situ RNA hybridization for Epstein-Barr virus (EBV)-encoded small RNAs (EBER-ISH) on LN tissue biopsies revealed atypical EBER localization in the cytoplasm of TECs. Stem-loop RT-PCR confirmed the presence of intact $167 \mathrm{nt}$ EBV-EBER1 RNA in LN tissues while EBV-DNA was virtually undetectable, arguing against EBVinfected (B) cells as an explanation for EBER1 detection. We hypothesised that cell-free EBER1 in circulation enters the renal tubular epithelium in predisposed individuals. We detected extracellular vesicle (EV) associated EBER1 in SLE patient sera but not in healthy and disease controls. We determined primary TEC express phosphatidylserine (PS) receptors, most notably Kidney-injury molecue-1 (KIM1), that support endocytosis of EBER1-loaded EVs. Purified EVs from EBVinfected B cells trigger an interferon stimulated gene expression (ISG) signature in TEC that is also expressed in LN tissues, but absent in renal disease control tissues. Immunohostochemstry further reveals TLR3 and KIM-1 protein expression in the renal epithelium of LN tissues. Importantly, hydroxychloroquine and Toll-like receptor-3 (TLR3) blockade inhibit EBER1-induced pro-inflammatory cytokine (IL-6 and TNFa) production in primary TECs. We propose that PS-mediated EV uptake by TECs and TLR3-mediated recognition of EBER1 induces pro-inflammatory cytokine expression may aggravate renal inflammation in human SLE. Our findings support the rationale for therapeutic blockade of TLR signalling in LN patients. Taken together our observations

10.1136/lupus-2018-abstract.10
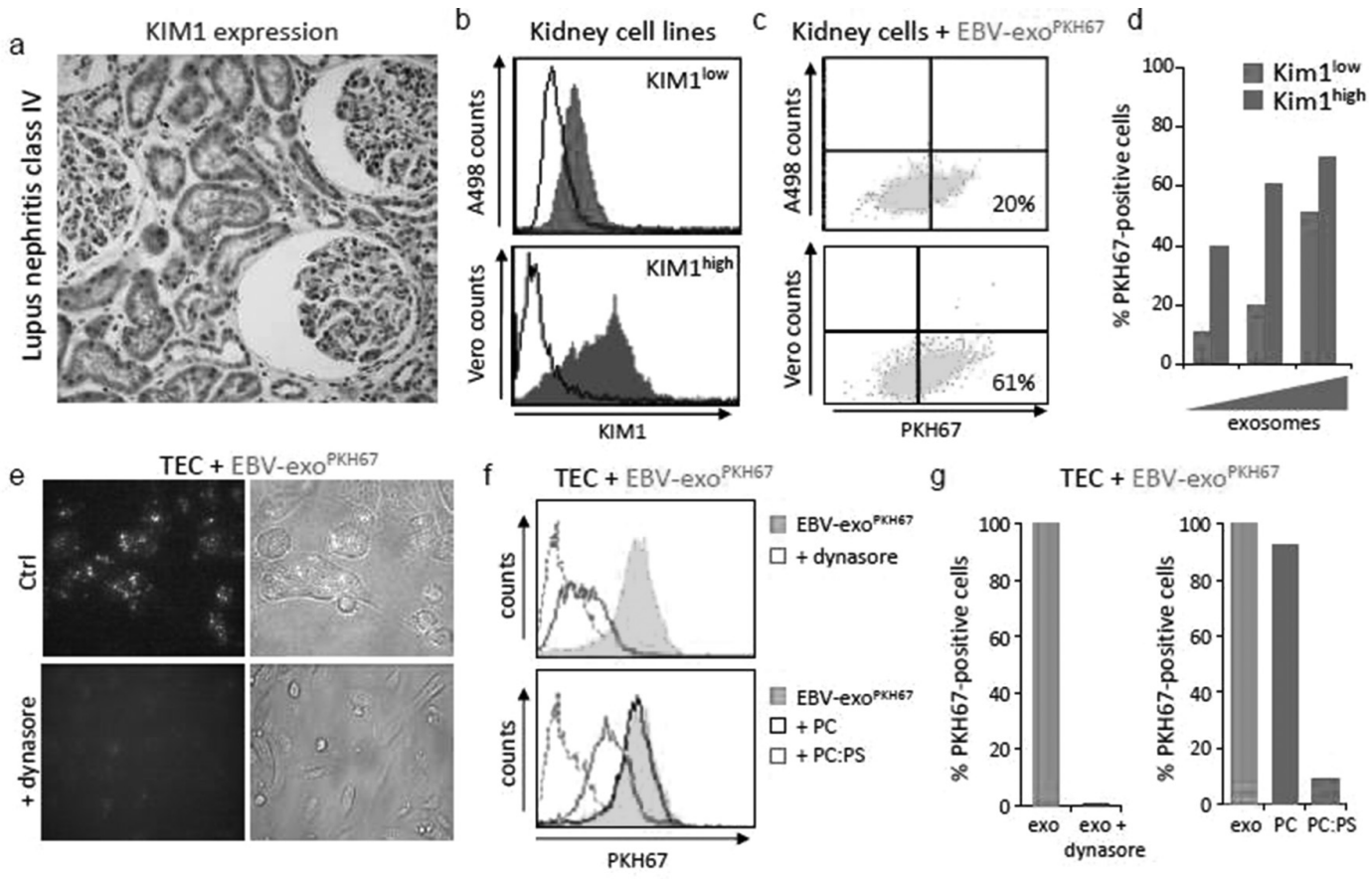

Abstract S2D:5 Figure 1 Renal epithelial cells internalise EBV-exosomes in a phosphatidylserine (PS)-department manner 